\title{
Приборы радиофотоники на основе фосфида индия
}

\author{
К.С. Журавлев ${ }^{1)}$, Д.В. Дмитриев ${ }^{1)}$, А.И. Торопов ${ }^{1)}$, М.С. Аксенов ${ }^{1)}$, Н.А. Валишева ${ }^{1)}$, \\ А.М Гилинский ${ }^{1)}$, И.Б. Чистохин ${ }^{1)}$, А.Л. Чиж ${ }^{2)}$, С.А. Малышев ${ }^{2)}$, К.Б. Микитчук ${ }^{2)}$ \\ ${ }^{1}$ Институт физики полупроводников им. А.В. Ржанова СО РАН, \\ Новосибирск, 630090, пр. Ак. Лаврентьева, 13 \\ ${ }^{2}$ ГНПО «Оптика, оптоэлектроника и лазерная техника» \\ Национальной академии наук Беларуси, Минск, Беларусь \\ тел:+7 (383) 330-4475, эл. почта: zhur@isp.nsc.ru
}

DOI 10.34077/RCSP2019-83

Развитие технологий передачи широкополосных сигналов по волоконно-оптическим линиям открыло новые возможности для создания систем передачи аналоговых СВЧ- и КВЧ-сигналов с характеристиками, недостижимыми при использовании традиционных сред передачи. Основные преимущества аналоговых волоконно-оптических линий по сравнению с существующими СВЧкабелями обусловлены малыми погонными потерями волоконно-оптических кабелей (менее 0,2 дБ/км против 1-10 дБ/м в СВЧ-кабеле), сверхширокополосностью оптического канала передачи, его невосприимчивостью к электромагнитным помехам и полной гальванической развязкой цепей, малыми массой и размерами. Благодаря этим преимуществам волоконно-оптические линии передачи аналоговых сигналов перспективны для использования в целом ряде применений - радиолокации, распределенных системах радиосвязи, измерительной СВЧ-технике.

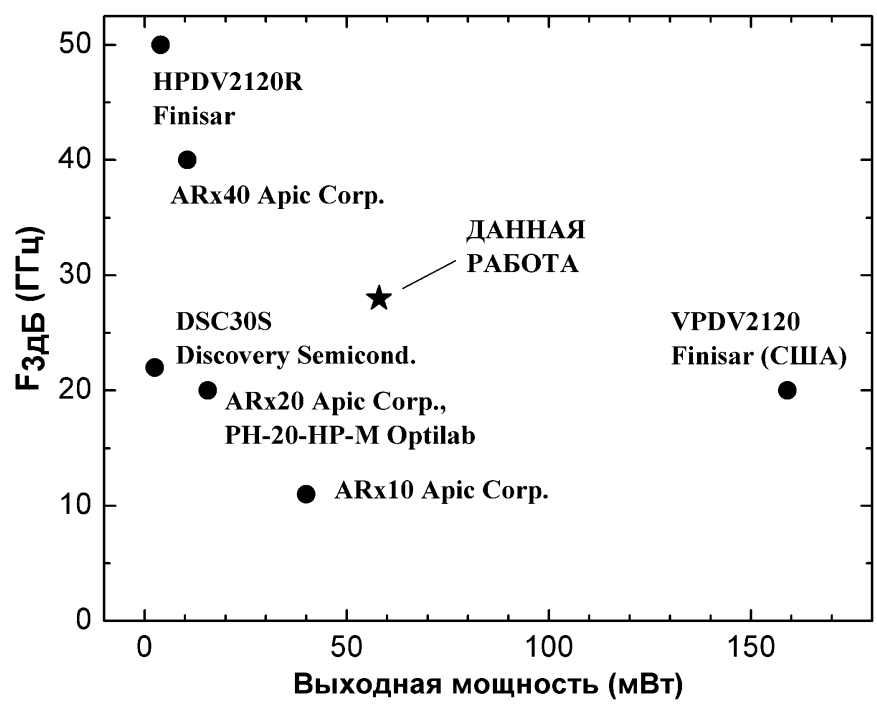

Для построения волоконнооптических линий передачи аналоговых СВЧ-сигналов с широким динамическим диапазоном необходимо использование мощных (десятки милливатт) лазеров, широкополосных модуляторов излучения и мощных фотодиодов, обеспечивающих выходной ток в десятки миллиампер (выходная СВЧмощность до десятков милливатт) в полосе частот до десятков гигагерц.

В настоящей работе рассматриваются современные подходы построения приборов радиофотоники на основе фосфида индия. Описываются разработанные конструкции и технологии изготовления мощных СВЧ-

фотодиодов и электроооптических модуляторов Маха-Цендера для применения в волоконнооптических линиях передачи СВЧ-сигналов, использующих диапазоны длин волн 1,33 и 1,55 мкм. Фотодиоды выполнены в виде чипов, изготавливаемых на основе двойной гетероструктуры InAlAs/InGaAs, выращиваемой на подложке InP методом молекулярно-лучевой эпитаксии. Чип фотодиода содержит меза-структуру с барьером Шоттки и массивными металлическими контактами, обеспечивающими высокую электро- и теплопроводность. Контакты фотодиодов выполняются в виде микрополосков, с помощью которых чипы фотодиодов монтируются непосредственно в СВЧлинию передачи. Подача излучения производится через подложку, прозрачную в указанном диапазоне длин волн.

Изготовленные фотодиоды демонстрируют низкие значения обратного темнового тока 0,050,2 нА. Высота барьера Шоттки фотодиодов составляет 0,7 В. Емкость фотодиодов с диаметром мезаструктуры 15 мкм при напряжении смещения -2 В равна $\approx 100$ фФ. Чувствительность фотодиодов составляет 0,45-0,55 А/Вт на длине волны 1,55 мкм. Предельная рабочая частота фотодиодов с диаметром фоточувствительной области 15 мкм, установленных в копланарную СВЧ-линию с волновым сопротивлением 50 Ом, составляет 28 ГГц. При этом максимальная выходная СВЧмощность фотодиода на частоте 20 ГГц равна 58 мВт. Достигнутые значения рабочей частоты и выходной мощности разработанных фотодиодов соответствуют текущему мировому уровню, иллюстрируемому на рисунке в сравнении с коммерчески доступными моделями. 